\title{
RESTORASI LAHAN PASCA TAMBANG TIMAH DI PULAU BANGKA
}

\section{Oleh :}

Fitri Ramdhani Harahap, S.Sos., M.Si

\begin{abstract}
Abstrak :
Kerusakan akibat penambangan timah di Pulau Bangka semakin meningkat terutama sejak berkembangnya penambangan inkonvensional. Dampak kegiatan penambangan timah, baik tambang konvensional maupun inkonvensional terhadap lingkungan fisik berupa bertambahnya lahan kritis akibat berkurangnya hutan, rusaknya lahan pertanian dan kebun. Upaya rehabilitasi lahan bekas tambang ditinjau dari aspek teknis adalah upaya untuk mengembalikan kondisi tanah agar stabil dan tidak rawan erosi. Dari aspek ekonomis dan estetika lahan, kondisi tanah diperbaiki agar nilai/ potensi ekonomisnya dapat dikembalikan sekurang-kurangnya seperti keadaan semula. Dari aspek ekosistem, upaya pengembalian kondisi ekosistem ke ekosistem semula. Dalam hal ini revegetasi adalah upaya yang dapat dinilai mencakup kepada kepentingan aspek-aspek tersebut, dimana reklamasi hampir selalu identik dengan revegetasi.
\end{abstract}

\section{Kata Kunci :}

Restorasi, Pasca Tambang Timah, Pulau Bangka

\section{PENDAHULUAN}

\subsection{Penambangan Timah di Kepulauan Bangka}

Indonesia mempunyai cadangan timah yang cukup besar dan telah ditambang lebih dari 300 tahun. Cadangan timah ini tersebar dalam bentangan wilayah sejauh lebih dari 800 kilometer, yang disebut The Indonesian Tin Belt (Sabuk Timah Indonesia). Bentangan ini merupakan bagian dari The Southeast Asia Tin Belt (Sabuk Timah Asia Tenggara) yang membujur sejauh kurang lebih $3.000 \mathrm{~km}$ dari daratan Asia ke arah Thailand, semenanjung Malaysia hingga Indonesia. Di Indonesia sendiri, wilayah cadangan timah mencakup Pulau Karimun, Kundur, Singkep, dan sebagian di daratan Sumatera (Bangkinang) di utara terus ke arah selatan yaitu Pulau Bangka, Belitung, dan Karimata hingga ke daerah sebelah barat Kalimantan. Penambangan di Bangka, telah dimulai pada tahun 1711, di Singkep pada tahun 1812, dan di Belitung sejak 1852. Namun, aktivi- tas penambangan timah lebih banyak dilakukan di Pulau Bangka, Belitung, dan Singkep. Kegiatan penambangan timah di pulau-pulau ini telah berlangsung sejak zaman kolonial Belanda hingga sekarang (Batubara, 2010).

Dari sejumlah pulau penghasil timah tersebut, Pulau Bangka merupakan pulau penghasil timah terbesar di Indonesia. Dari luas Pulau Bangka 1.294.050 ha, sebesar 27,56 \% daratan pulau ini merupakan areal Kuasa Penambangan (KP) timah. PT. Tambang Timah (anak perusahaan PT. Timah Tbk) menguasai lahan seluas 321.577 ha dan PT. Kobatin seluas 35.063 ha. Selain kedua perusahan tersebut, izin kuasa penambangan (KP) timah juga diberikan kepada perusahaan swasta. Sampai dengan pertengahan tahun 2007, jumlah KP timah mencapai 101 izin dengan luas pencadangan 320.219 ha, dan yang telah ditambang 6.084 ha (Inonu, 2013).

Perubahan kontrol terhadap timah terjadi setelah era Reformasi. Menteri Perindustrian dan 
Perdagangan mengeluarkan keputusan yang tidak lagi mencantumkan kata 'timah' dalam daftar barang-barang ekspor yang diawasi atau diatur pemerintah Keputusan Menperindag No. 146/MPP/ Kep/4/1999 tanggal 22 April 1999. Keputusan ini berimplikasi bahwa siapapun berhak memasarkan timah. Hal ini kemudian diikuti dengan dikeluarkan peraturan daerah Nomor 6 Tahun 2001 yang pada dasarnya memberi akses kepada masyarakat Bangka untuk menambang (Erman, 2008). Kabupaten Bangka Tengah kemudian mengikuti dengan mengeluarkan Peraturan Daerah Nomor 08 tahun 2007 tentang pokokpokok pertambangan umum. Hal ini kemudian menjadikan pertambangan di Bangka Belitung tumbuh tanpa terkendali dan pengawasan terhadap lingkungan tidak terlihat sehingga dampak lingkungan dari penambangan ini terlihat jelas. Semua kabupaten di Provinsi Kepulauan Bangka Belitung telah terjadi perubahan penggunaan lahan karena aktivitas penambangan.

Di Kepulauan Bangka dijumpai 2 sistem penambangan biji timah yakni tambang semprot dan tambang kapal keruk. Pada tambang semprot, sistem penambangan biji timah dibagi dalam 3 tahapan (1). Pengupasan: pada tahap ini dilakukan pembongkaran lapisan tanah atau batuan yang tidak mengandung biji timah (overburden) yang dapat mencapai kedalaman tertentu. Lapisan tanah yang dikupas terdiri atas: a) top soil (tanah pucuk) yang telah mengalami pelapukan sehingga merupakan media tumbuh yang baik bagi tanaman, dan b) bahan induk tanah yang belum mengalami pelapukan. (2) Penyemprotan: kegiatan ini bertujuan untuk membongkar atau melarutkan tanah/batuan yang mengandung biji timah sehingga berubah menjadi lumpur. Lumpur yang mengandung biji timah ini kemudian dipompa/ dialirkan ke instalasi pencucian (disebut palong atau sakam). Penyemprotan akan meninggalkan lubang-lubang (kolong-kolong) dengan kedalaman bervariasi $(6-10 \mathrm{~m})$ dengan luas beberapa hektar dan di musim hujan, kolong pasca penambangan ini akan terisi air. (3) Pencucian: Kegiatan ini bertujuan untuk memisahkan biji timah dari bahan lainnya. Pemisahan menggunakan sistem gravitasi dimana biji timah dengan berat jenis $7,2 \mathrm{~g} / \mathrm{cm} 3$ akan lebih dulu mengendap, disusul dengan pasir kasar (tailing) dan kerikil dengan berat jenis 2-4 g/ $\mathrm{cm}^{3}$ dan yang lebih jauh dan terakhir mengendap adalah lumpur (slime). Dari proses pencucian ini akan menghasilkan tailing dengan kandungan bahan organik sangat rendah, miskin unsur hara, kapasitas menyimpan air sangat rendah), serta bagian lumpur yang jenuh air. Hamparan pasir tailing yang berbentuk bukit-bukit kecil mengandung pasir 90\%; debu $8 \%$; liat 0,5\%; Corganik 0,10\%; KTK 0,5 me/100 mg (P4LH-Puslittanak, 1996) dan temperatur permukaan tanah sangat tinggi (40-500C) sehingga evaporasi cukup tinggi. Selain lereng, faktor lain yang berpengaruh terhadap besarnya erosi dan degradasi lahan adalah tanah dan curah hujan. Bentuk wilayah berombak sampai bergelombang merupakan faktor yang mendorong terjadinya erosi dan degradasi lahan, dengan rata-rata curah hujan $\pm 2.339 \mathrm{~mm} /$ tahun (Juarsah, 2011).

\subsection{Dampak Praktek Penambangan Timah}

Kerusakan akibat penambangan timah di Pulau Bangka semakin meningkat terutama sejak berkembangnya penambangan inkonvensional. Sebelum tahun 1998, komoditi timah termasuk komoditi strategis yang perdagangannya terbatas, sehingga kegiatan penambangan dan perdagangan timah hanya boleh dilakukan oleh perusahaan PT. Timah dan PT, Koba Tin. Pada tahun 1998 terjadi krisis ekonomi di Indonesia. Atas permintaan Bupati Bangka, PT Timah Tbk men- 
gizinkan masyarakat menambang di sebagian wilayah kuasa penambangan (KP) yang sudah ditinggalkan. Sebagai timbal baliknya dan untuk memenuhi ketentuan mengenai barang tambang strategis, masyarakat harus menjual pasir timahnya hanya kepada PT Timah. Semenjak saat itu dikenal isitilah tambang inkonvensional (TI). Disebut sebagai tambang inkonvensional karena metode penambangannya tidak seperti penambangan terbuka (open mining), tetapi hanya dengan mesin penyedot tanah dan air. Dampak kegiatan penambangan timah, baik tambang konvensional maupun inkonvensional terhadap lingkungan fisik berupa bertambahnya lahan kritis akibat berkurangnya hutan, rusaknya lahan pertanian dan kebun. Menurut hasil rekapitulasi Bapedalda Provinsi Kepulauan Bangka Belitung (2005), luas hutan di Propinsi Kepulauan Bangka Belitung $\pm 690.092 \mathrm{Ha}$, seluas $\pm 97.159 \mathrm{Ha}(14 \%)$ telah mengalami kerusakan. Lahan kritis yang terbentuk juga semakin meningkat, sampai tahun 2005 di Pulau Bangka seluas 464.673 Ha. Selain itu, dilaporkan juga bahwa semua sungai besar yang ada, seperti Sungai Kepoh, Sungai Antan, Sungai Kampak, Sungai Mancung dan Sungai Kurau umumnya sudah tercemar terutama kekeruhan akibat partikel tanah dari pencucian pasir timah yang mengalir ke sungai-sungai (Inonu, 2013).

\section{PEMBAHASAN}

\subsection{Prinsip-prinsip Restorasi}

Restorasi biasanya terdiri dari kegiatan reklamasi (melibatkan kegiatan civil engineering, berhubungan dengan pemulihan kondisi tanah) dan revegetasi (mengembalikan pohon, shrub, dan lain-lain).

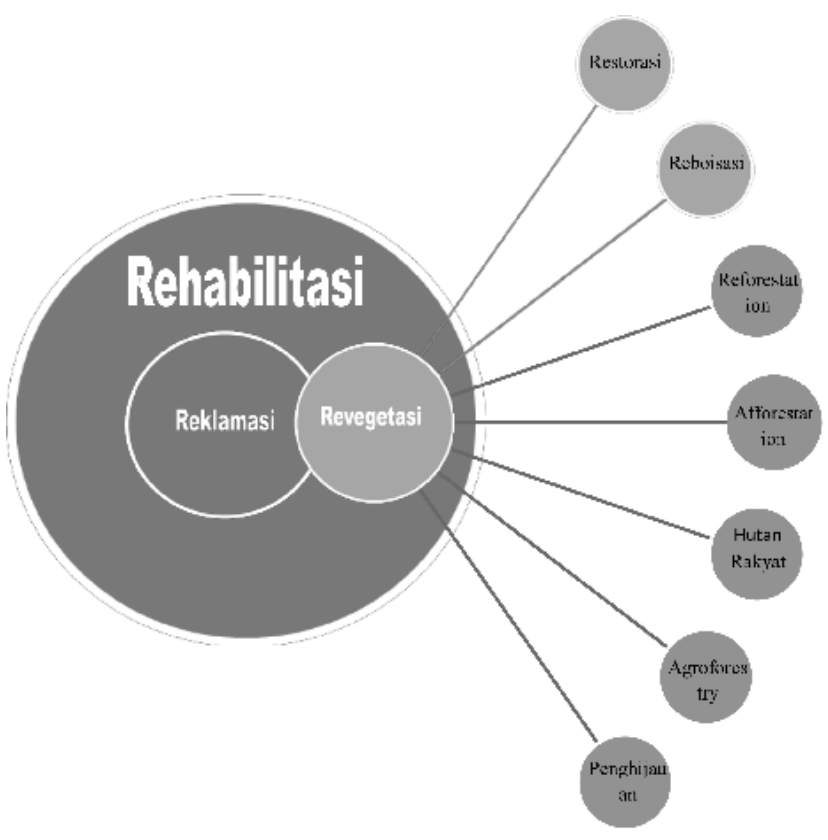

Dalam kaitannya dengan rehabilitasi, rehabilitasi merupakan suatu general term untuk suatu kegiatan revegetasi yang tidak mempunyai tujuan spesifik, atau lebih jelasnya dapat dilihat pada diagram di atas. Restorasi didefinisikan sebagai upaya memperbaiki atau memulihkan kondisi lahan yang rusak dengan membentuk struktur dan fungsinya sesuai (mendekati) dengan kondisi awal.

The Society for Ecological Restoration International menawarkan definisi sebagai berikut :"Restorasi ekologi adalah proses untuk membantu pemulihan suatu ekosistem yang telah menurun, rusak, atau hancur." Kutipan tersebut menegaskan bahwa intervensi restorasi diciptakan untuk membantu proses-proses pemulihan alami. Apabila proses pemulihan alami tersebut tidak berjalan, bentuk pengelolaan lain dibutuhkan sebelum intervensi restorasi berpeluang sukses. "Bantuan" kita dalam pemulihan alami dapat berupa bentuk pasif atau secara tidak langsung, atau dalam bentuk aktif atau intervensi langsung. Yang pertama umumnya melibatkan perbaikan pengelolaan aktivitas antropogenik yang menghalangi proses pemulihan alami; sementara yang terakhir biasanya melibatkan restorasi fisik 
aktif dan/atau intervensi restorasi biologis, contohnya transplantasi karang dan biota lainnya ke daerah yang terdegradasi (Edwards, A.J. \& Gomez, E.D, 2008).

Menurut Sutomo (2011) ekologi restorasi bertujuan untuk: (1). Merestorasi situs terlokalisasi yang terganggu atau rusak seperti bekas areal tambang. (2). Untuk meningkatkan kemampuan produktivitas di lahan produksi yang terdegradasi. (3). Memperkaya nilai-nilai konservasi alam di areal lanskap yang dilindungi. (4). Merestorasi proses-proses ekologis di dalam suatu lanskap yang luas. Restorasi ekologi menaungi berbagai dimensi dari upaya restorasi yang lebih luas tidak hanya mencakup ekologi restorasi, tetapi juga dari sisi kajian sosial, kebijakan dan ekonomi untuk mencapai tujuannya.

\subsubsection{Reklamasi}

Menurut Latifah (2003) dampak negatif kegiatan pertambangan terhadap lingkungan tersebut perlu dikendalikan untuk mencegah kerusakan di luar batas kewajaran. Prinsip kegiatan Reklamasi adalah : (1). kegiatan Reklamasi harus dianggap sebagai kesatuan yang utuh dari kegiatan penambangan (2). kegiatan Reklamasi harus dilakukan sedini mungkin dan tidak harus menunggu proses penambangan secara keseluruhan selesai dilakukan.

Kegiatan reklamasi terdiri dari dua kegiatan yaitu : (1). Pemulihan lahan bekas tambang untuk memperbaiki lahan yang terganggu ekologinya, dan (2). Mempersiapkan lahan bekas tambang yang sudah diperbaiki ekologinya untuk pemanfaatannya selanjutnya. Untuk melakukan reklamasi lahan bekas tambang diperlukan perencanaan yang baik agar dalam pelaksanaannya dapat tercapai sasaran sesuai yang dikehendaki. Hal-hal yang harus diperhatikan didalam perencanaan reklamasi adalah sebagai berikut :
1. Mempersiapkan rencana reklamasi sebelum pelaksanaan penambangan.

2. Luas areal yang direklamasikan sama dengan luas areal penambangan.

3. Memindahkan dan menempatkan tanah pucuk pada tempat tertentu dan mengatur sedemikian rupa untuk keperluan revegetasi.

4. Mengembalikan/memperbaiki pola drainase alam yang rusak

5. Menghilangkan/memperkecil kandungan (kadar) bahan beracun sampai tingkat yang aman sebelum dapat dibuang ke suatu tempat pembuangan.

6. Mengembalikan lahan seperti keadaan semula dan/atau sesuai dengan tujuan penggunaannya.

7. Memperkecil erosi selama dan setelah proses reklamasi.

8. Memindahkan semua peralatan yang tidak digunakan lagi dalam aktifitas penambangan.

9. Permukaan yang padat harus digemburkan namun bila tidak memungkinkan agar ditanami dengan tanaman pionir yang akarnya mampu menembus tanah yang keras.

10. Setelah penambangan maka pada lahan bekas tambang yang diperuntukkan bagi revegetasi, segera dilakukan penanaman kembali dengan jenis tanaman yang sesuai dengan rencana rehabilitasi dari Departemen Kehutanan dan RKL yang dibuat.

11. Mencegah masuknya hama dan gulma yang berbahaya.

12. Memantau dan mengelola areal reklamasi sesuai dengan kondisi yang diharapkan.

Setiap lokasi pertambangan mempunyai kondisi tertentu yang mempengaruhi pelaksanaan reklamasi. Pelaksanaan reklamasi umumnya merupakan gabungan dari pekerjaan teknik 
sipil dan teknik vegetasi. Pelaksanaan reklamasi meliputi kegiatan sebagai berikut :

- Persiapan lahan yang berupa pengamanan lahan bekas tambang, pengaturan bentuk lahan (landscaping), pengaturan/ penempatan bahan tambang kadar rendah (lowgrade) yang belum dimanfaatkan.

- $\quad$ Pengendalian erosi dan sidementasi.

- Pengelolaan tanah pucuk (top soil).

- Revegetasi (penanaman kembali) dan/atau pemanfaatan lahan bekas tambang untuk tujuan lainnya.

Arah dari upaya rehabilitasi lahan bekas tambang ditinjau dari aspek teknis adalah upaya untuk mengembalikan kondisi tanah agar stabil dan tidak rawan erosi (Sujitno, 2007). Dari aspek ekonomis dan estetika lahan, kondisi tanah diperbaiki agar nilai/potensi ekonomisnya dapat dikembalikan sekurang-kurangnya seperti keadaan semula. Dari aspek ekosistem, upaya pengembalian kondisi ekosistem ke ekosistem semula. Dalam hal ini revegetasi adalah upaya yang dapat dinilai mencakup kepada kepentingan aspek-aspek tersebut. Reklamasi hampir selalu identik dengan revegetasi.

\subsubsection{Revegetasi}

Revegetasi adalah usaha atau kegiatan penanaman kembali lahan bekas tambang. Tujuan dari revegetasi akan mencakup re-establishment komunitas tumbuhan seeara berkelanjutan untuk menahan erosi dan aliran permukaan, perbaikan biodiversitas dan pemulihan estetika lanskap. Pemulihan lanskap secara langsung menguntungkan bagi lingkungan melalui perbaikan habitat hewan, biodiversitas, produktivitas tanah dan kualitas air (Tjabyana dan Yulius, 2011).

Menurut Latifah (2003) Keberhasilan revegetasi bergantung pada beberapa hal seperti
: Persiapan penanaman, pemeliharaan tanaman serta pemantauan tanaman. Hal-hal yang harus diperhatikan dalam persiapan penanaman antara lain sebagai berikut :

- Kegiatan pemupukan

- Pemilihan jenis tumbuhan

- Pengumpulan dan ekstraksi biji

- Penyimpanan biji

- Persiapan pembenihan

Terdapat beberapa pilihan tentang metoda penanaman kembali dari tumbuhan asli apabila diperlukan. Metoda penanaman yang dipilih akan bergantung pada ukuran dan sifat dari lokasi dan tersedianya jenis tanaman. Beberapa menetapkan pilihan antara lain : Penyemaian langsung, penanaman semaian dan pencangkokan. Tingkat keberhasilan dari semua metoda penanaman akan berkurang bila tidak dilakukan pemeliharaan yang baik. Untuk itu perlu dilakukan hal-hal berikut :

- Pemagaran atau perlindungan tiap pohon diperlukan tetapi tidak pada penanaman skala besar. Pemagaran keliling akan memberikan perlindungan terhadap ternak pemakan tunas, lalu lintas kendaraan dan pejalan kaki. Pagar sementara kurang dapat memberikan perlindungan yang baik untuk jangka waktu yang lama. Pemagaran keliling dilengkapi dengan penahan angin akan meningkatkan keberhasilan program revegetasi.

- Hindarkan pengairan yang berlebihan pada daerah yang sudah ditabur dengan biji sampai tiba musim hujan.

- Penyiraman semaian harus dikurangi sedikit demi sedikit untuk mencegah ketergantungan yang berlebihan atau terjadinya akar permukaan.

Penggunaan pupuk, tambahan biji atau penyulaman penanaman. 
- Kerusakan akibat serangga dan kutu adalah hal biasa, khususnya bila program revegetasi menghasilkan tanaman atau rumput-rumputan yang jarang didapati di daerah tersebut.

\subsection{Restorasi sebagai Upaya Pemulihan Lahan Pasca Tambang Timah}

Kontribusi sektor pertambangan terhadap kerusakan hutan di Indoensia mencapai 10\% dan kini melaju mencapai 2 juta ha per tahun. Di Bangka-Belitung luas lahan bekas pertambangan timah sudah mencapai 400.000 ha yang terdiri dari $65 \%$ lahan tandus dan 35\% berbentuk telaga-telaga. Reklamasi terhadap lahan bekas tambang tirnah tersebut telah dilakukan, pada tahun 1992-2008 perusahaan tambang timah telah mereklamasi sekitar 11.000 ha, pada tahun 2008 seluas 2.000 ha dan selanjutnya direncanakan reklamasi dilakukan seluas 1.600 ha per tahun.

Selama ini reklamasi lahan bekas tambang dilakukan dengan menanaman tanaman akasia (A. mangium dan A. auriculiformisi, gamal dan sengon, tanaman lainnya seperti kelapa, jambu monyet, pisang, pepaya, kacang tanah sayuran. Budidaya tanaman tersebut dikombinasikan dengan usaha perternakan ayam yang merupakan sumber bahan organik bagi lahan ini. Namun budidaya pertanian di tailing timah sangat intensif dan membutuhkan masukan modal yang besar dan tentu sulit untuk dilaksanakan oleh petani umumnya. Pada dasarnya kegiatan reklamasi harus seimbang dengan pembukaan tambang, tetapi sering reklamasi lahan yang sudah dilakukan, kembali rusak yang disebabkan oleh penambangan ilegal yang dilakukan masyarakat setempat. Hal ini terjadi disebabkan oleh beberapa hal antara lain hasil penambangan dapat langsung dijual tidak memerlukan waktu yang panjang dan harga menguntungkan, sedangkan tanaman ha- sil reklamasi belum memberikan nilai ekonomi yang berarti bagi masyarakat (Tjabyana dan Yulius, 2011).

Menurut Inonu (2003) pemilihan spesies tanaman untuk revegetasi merupakan tahap yang paling penting dalam upaya merestorasi lahan tambang. Untuk memastikan keberhasilan penanaman pohon pada lahan yang mengalami degradasi dan mengembalikan fungsi ekosistem memerlukan suatu strategi yang meliputi pemilihan jenis tumbuhan asli yang dapat menyesuaikan diri dengan kondisi iklim lokal dan kondisi lahan yang ada, serta melalui pendekatan aplikasi teknik revegetasi mencakup perlakuan silvikultur, perbaikan lahan, dan pengelolaan lahan. Untuk menghijaukan kembali lahan tailing timah, salah satu strategi yang perlu diperhatikan adalah seleksi spesies. Pemilihan jenis tanaman yang akan ditanam didasarkan pada adaptabilitas, cepat tumbuh, teknik silvikultur diketahui, ketersediaan bahan tanaman, serta dapat bersimbiosis dengan mikroba. Tanaman yang dipilih berupa spesies yang cepat tumbuh, resisten terhadap kekeringan, dan mampu tumbuh pada tanah yang miskin unsur hara (ITTO 2002 dalam Nurtjahya 2003). Ditinjau dari aspek konservasi lahan, revegetasi dengan menggunakan jenis MPTS yang telah dilakukan berhasil menghijaukan kembali lahan-lahan bekas tambang serta mampu mencegah erosi. Secara ekologi, penghutanan kembali lahan bekas tambang dengan MPTS terutama tanaman akasia kurang menunjukkan keragaman spesies karena tanaman akasia menghasilkan eksudat akar yang bersifat alelopati bagi tanaman lain. Selain itu, perkembangbiakan akasia melalui biji dan vegetatif (tunas akar) cenderung ekstensif. Kedua hal tersebut menghambat pertumbuhan tanaman lain yang ada di sekitarnya, sehingga vegetasi cenderung homogen. Selain itu, apabila tanaman ini akan 
dimanfaatkan untuk bahan baku pulp dan kertas harus melalui penebangan dan penanaman kembali. Metode revegetasi ke depan perlu mengembangkan spesies-spesies lain untuk revegetasi selain spesies yang sudah ada. Idealnya, spesies revegetasi yang digunakan adalah spesies yang memenuhi persyaratan sebagai tanaman reklamasi, secara teknis dapat dilaksanakan dengan mudah dan murah dan secara ekonomis, menghasilkan produk yang bermanfaat (kayu dan non kayu). Jenis-jenis tanaman perkebunan (misalnya karet dan kelapa sawit), tanaman buah (misalnya mangga, jeruk, jambu air), tanaman kehutanan spesifik Bangka perlu dikembangkan sebagai alternatif. Di lahan rekalamasi PT. Koba Tin, beberapa tanaman tersebut berhasil tumbuh dan berproduksi.

Penanaman tanaman karet (Hevea brasiliensis Muell Arg) di lahan bekas tambang dinilai merupakan salah satu alternatif utama untuk mengatasi tidak produktifnya lahan tandus bekas tambang timah tersebut, masalah lingkungan yang ditimbulkan oleh sisa penambangan dan sekaligus memecahkan masalah perekonomian masyarakat. Beberapa hal kenapa tanaman karet berpotensi dikembang di lahan bekas bekas tambang. Pertama, tanaman karet termasuk tanaman multiguna (multipurpose tree species, MPTS), mempunyai adaptasi yang tinggi pada lahan-lahan marginal, seperti di lahan yang berbatu di Sulawesi Selatan. Tanaman karet mempunyai akar tunggang yang dalam secara teoritas lebih mampu mengatasi masalah kekeringan. Tanaman karet bahkan mampu memberikan produktivitas yang lebih tinggi pada lahan berpasir dengan bulan kering yang tegas dibandingkan dengan lahan yang tidak memeiliki bulan kering. Kedua, tanaman karet mampu memperbaiki sifat tanah melalui pekayaan hara dengan karakter fisiologi pengguguran daunnya. Selain itu tanaman karet dapat disadap dan menghasilkan getah hampir setiap hari sehingga menghasilkan pandapatan yang dibutuhkan oleh masyarakat.

Penelitian di Malaysia menunjukkan bahwa setiap tahun daun karet dapat mengembalikan 45-90 kg/ha N, 3-7 kg/ha P, 10-20 kg/ha K dan 9-18 kg/ha $\mathrm{Mg}$. Melalui pengguguran daunnya, ini merupakan karisteristik tanaman karet. Dengan demikian diharapkan pemulihan lahan bekas tambang dapat lebih cepat terjadi. Untuk daerah Bangka Belitung tanaman karet bukan tanaman baru, petani sudah sangat mengenal budidaya tanaman ini walaupun belum menggunakan benih unggul, selain itu tanaman karet dapat dikatakan menghasilkan pendapatan hampir tiap hari sehingga dapat memenuhi kebutuhan hidup keluarga tani sehari-hari. Selain itu saat ini telah tersedia klon karet penghasil Iatekskayu, sehingga selain menghasilkan lateks juga menghasilkan kayu untuk memenuhi kebutuhan kayu pertukangan dan meubiler (Boerhendhy dalam Tjabyana dan Yulius, 2011).

Reklamasi lahan bekas penambangan timah ke depan bertumpu pada pemanfaatan berbagai sumber bahan organik dan pemilihan spesies revegetasi yang tepat guna. Bahan-bahan organik yang tersedia secara lokal di Provinsi Kepulauan Bangka Belitung, khususnya Pulau Bangka dapat dimanfaatkan untuk membenahi lahan bekas penambangan timah. Potensi bahan organik seperti tandan kosong kelapa sawit, limbah cair pabrik pengolahan kelapa sawit cukup tersedia di Pulau Bangka. Selama ini pemanfaatan limbah tersebut hanya terbatas untuk menambah unsur hara tanaman kelapa sawit milik perusahaan melalui aplikasi lahan (land application) dan belum pernah digunakan untuk memperbaiki karakteristik lahan bekas penambangan timah. Potensi bahan organik sampah kota Di Kota Pangkalpinang dan Sungailiat, tempat pem- 
buangan akhir sampah (TPA) sudah dilengkapi dengan alat pencacah sampah organik. Setelah dicacah, sampah organik tersebut dapat didekomposisi lebih lanjut menjadi kompos yang dapat digunakan sebagai bahan pembenah tanah pada reklamasi lahan bekas tambang timah. Demikian juga kotoran ternak seperti ayam potong dan sapi yang dihasilkan sejumlah peternakan di Pulau Bangka berpotensi untuk dimanfaatkan dalam program reklamasi. Meskipun potensinya cukup besar, penelitian mengenai efektivitas bahan-bahan tersebut bagi perbaikan lahan bekas tambang timah sejauh ini belum pernah dilakukan.

Permasalahan utama reklamasi dan revegetasi lahan bekas tambang timah di Provinsi Bangka Belitung adalah pembukaan lahan yang telah direklamasi oleh penambang ilegal. Lemahnya supremasi hukum dan kebutuhan ekonomi masyarakat yang sangat tergantung dengan timah memicu penambangan kembali lahan-lahan bekas tambang timah PT Timah dan PT Koba Tin oleh masyarakat yang dikenal dengan tambang inkonvensional. Lahan bekas tambang, baik yang belum direklamasi maupun yang telah direklamasi akan ditambang kembali oleh masyarakat untuk mengambil deposit biji timah yang masih tersisa. Kegiatan ini menghambat pemulihan lahan pasca penambangan karena lahan tersebut harus direklamasi dan direvegetasi kembali yang membutuhkan tambahan biaya dan waktu. Bahkan sejak tahun 2001, PT. Timah untuk sementara menghentikan program reklamasinya dan baru dilanjutkan kembali pada tahun 2006 (Inonu, 2013).

\section{PENUTUP}

\subsection{Kesimpulan}

Pelaksanaan reklamasi lahan umumnya merupakan gabungan dari pekerjaan teknik sipil dan teknik vegetasi. Perencanaan dan pelaksanaan reklamasi lahan tambang yang dilakukan secara tepat diharapkan dapat memperoleh hasil yang optimal.

Masalah-masalah dalam reklamasi dan revegetasi lahan di Pulau Bangka antara lain pembongkaran kembali lahan yang telah direklamasi oleh masyarakat, manajemen pengelolaan tanah bekas galian yang tidak tepat dan pemilihan spesies revegetasi yang kurang bermanfaat secara ekonomis bagi masyarakat lokal. 


\section{DAFTAR PUSTAKA}

Batubara, Marwan., 2010, Menyelamatkan Kehancuran Pertambangan Timah Bangka Belitung (1), http://www.eramuslim.com, diakses pada tanggal 23 Januari 2010.

Edwards, A.J. \& Gomez, E.D. 2008. Konsep dan panduan restorasi terumbu: membuat pilihan bijak di antara ketidakpastian. Terj. dari Reef Restoration Concepts and Guidelines: making sensible management choices in the face of uncertainty. Oleh: Yusri, S., Estradivari, N. S. Wijoyo, \& Idris. Yayasan TERANGI, Jakarta.

Erman, Erwiza., 2008, Rethingking Legal and Illegal Economy: A Case Study of Tin Mining in Bangka Island, Jurnal Southeast Asia; History and Culture, Vol. 37, p. 91-111.

Inonu, Ismed., 2013, Pengelolaan Lahan Tailing Timah di Pulau Bangka: Penelitian yang Telah Dilakukan dan Prospek ke Depan, http:// download.portalgaruda.org/article.php?ar$\underline{\text { ticle }}=273888 \& \mathrm{val}=5433 \&$ title $=$ Pengelolaan\%20Lahan\%20Tailing\%20Timah\%20 di\%20Pulau\%20Bangka:\%20Penelitian\%20yang\%20Telah\%20Dilakukan \%20 dan $\% 20$ Prospek $\% 20 \mathrm{ke} \% 20$ Depan, diakses pada tanggal 1 September 2015.

Juarsah, Ishak., 2011, Kondisi Sifat Fisik Tanah Dan Lingkungan Pada Lahan Pasca Penambangan Timah Di Propinsi Bangka Belitung, http://www.pustaka.ut.ac.id/dev25/pdfprosiding2/fmipa201110.pdf, diakses pada tanggal 1 September 2015.

Latifah, Siti., 2003, Kegiatan Reklamasi Lahan Pada Bekas Tambang, http://repository.usu. ac.id/bitstream/123456789/920/1/hutan-siti1.pdf, diakses pada tanggal 2 September 2015.

Sujitno, Sutedjo., 2007, Sejarah Penambangan Timah di Indonesia Abad 18 - Abad 20, Iba- lat Communication, Jakarta.

Sutomo, Restorasi Ekologi, http://u.lipi. go.id/1321050669, diakses pada tanggal 2 September 2015.

Tjabyana, Bambang Eka., Yulius Ferry, 2011, Revegetasi Lahan Bekas Tambang Timah dengan Tanaman Karet (Hevea Brasiliensisi), Prosiding Seminar Nasional Inovasi Perkebunan. 